\title{
Mycorrhizal Infection Reduces Short- term Aluminum Uptake and Increases Root Cation Exchange Capacity of Highbush Blueberry Plants
}

\author{
Wei Qiang Yang ${ }^{1}$ and Barbara L. Goulart \\ Department of Horticulture, The Pennsylvania State University, University \\ Park, PA 16802-4200
}

\begin{abstract}
Additional index words. aurintriboxylic acid stain, ericoid mycorrhizae, Vaccinium corymbosum
\end{abstract}

\begin{abstract}
Aluminum (Al) uptake by and root cation exchange capacity (CEC) of mycorrhizal (M) and nonmycorrhizal (NM) blueberry (Vaccinium corymbosum $\mathrm{L}$.) plants were studied. Root CEC was higher in M plants than in NM plants, but total and root Al contents were higher in NM plants. Leaf Al content was higher in NM than in M plants after 1 and 5 hours of exposure. The aurintriboxylic acid stain for $\mathrm{Al}$ indicated the presence of $\mathrm{Al}$ in the $M$ symbiont. Despite a larger root system and higher root $\mathrm{CEC}$, regression analysis indicated roots of $\mathrm{M}$ plants absorbed less $\mathrm{Al}$ in the first 5 hours, suggesting that $\mathrm{Al}$ sequestration in the $M$ symbiont is responsible for reduced total Al uptake. Differences in dry matter partitioning between $\mathrm{M}$ and NM plants were also observed.
\end{abstract}

Excess aluminum is toxic to many crops (Foy et al., 1978), and the potential for Al toxicity in rabbiteye blueberry (Vaccinium ashei Reade) plants during soil acidification has been documented (Patten et al., 1988; Peterson et al., 1987). Korcak (1989) found that the shoot fresh weight of highbush blueberry plants was reduced by high $\mathrm{Al}$ under a high Ca regime in solution culture. Our previous experiments have also demonstrated that high Al concentration inhibited growth of highbush blueberry plants by reducing nitrogen and phosphorus uptake (Yang and Goulart, 1997).

Ecto- and vesicular-arbuscular mycorrhizae alter plant responses to Al. Ecto- and endomycorrhizal infection increased host dry weight and decreased tissue $\mathrm{Al}$ content under relatively high $\mathrm{Al}$ concentrations (Cumming and Weinstein, 1990; Koslowsky and Boerner, 1989). Other studies have shown that Al ions are sequestered in the ecto- and endomycorrhizal symbionts (Eeckhaoudt et al., 1992; Maddox and Soileau, 1991). As a result, Al uptake is less in mycorrhizal (M) than in nonmycorrhizal (NM) plants. While no studies are known to examine the effect of ericoid mycorrhizae on the mediation of $\mathrm{Al}$

Received for publication 14 Dec. 1998. Accepted for publication 24 May 1999. We thank Yildiz H. Akin and Marvin L. Risius, for their advice on data analysis; James F. Hancock and Pete Callow, for their generous supply of tissue-cultured clonal blueberry shoots; and Kathleen Demchak, for her technical assistance. The cost of publishing this paper was defrayed in part by the payment of page charges. Under postal regulations, this paper therefore must be hereby marked advertisement solely to indicate this fact.

${ }^{1}$ Current address: Boyce Thompson Institute for Plant Research, Tower Road, Ithaca, NY 14850. E-mail address: wqy1@ cornell.edu toxicity, the ericoid mycorrhizal fungi tolerate very high $\mathrm{Al}$ concentration $\left(\leq 400 \mu \mathrm{g} \cdot \mathrm{mL}^{-1}\right)$ in pure culture (Burt et al., 1985). Mycorrhizal association with ericaceous plants also increases the ability of plants to tolerate high copper and zinc concentrations (Bradley et al., 1982). One can hypothesize, therefore, that ericoid mycorrhizal infection may also increase plant resistance to $\mathrm{Al}$.

Root cation exchange capacity (CEC) is related to aluminum tolerance. High root CEC may contribute to increased Al sensitivity, while low root CEC has been associated with resistance to aluminum uptake (Blamey et al., 1990; Vose and Randall, 1962). Root CEC was also negatively correlated with aluminum tolerance in wheat (Triticum aestivum L.) and barley (Hordeum vulgare L.) cultivars (Foy et al., 1967). Many factors, such as root nitrogen content, heavy metals, metabolic inhibitors, and growth regulators, affect root CEC (Crooke, 1958; Helmy and Elgabaly, 1958; Kennedy et al., 1986). We hypothesized that the $\mathrm{M}$ infection of blueberry plant roots could alter root CEC, and could be a mechanism by which uptake of $\mathrm{Al}$ and other ions might be altered in M blueberry plants. Therefore, the objectives of this study were: 1 ) to determine the effect of $M$ infection on short term aluminum uptake in blueberry plants; and 2) to determine how $\mathrm{M}$ infection affects the root CEC.

\section{Materials and Methods}

Aluminum (Al) uptake study. Meristem-tip cultured 'Elliott' highbush blueberry plants were propagated by rooting shoots in acidwashed sand as described previously (Yang and Goulart, 1997). An ericoid mycorrhizal isolate, Oidiodendron maius Sigler (UAMH 9263, identified by L. Sigler at the Univ. of Alberta, Canada) isolated from the roots of local lowbush blueberry (Vaccinium angustifolium Ait.) plants (Stevens et al., 1996), was used for inoculating highbush blueberry plants. This isolate was effective in infecting highbush blueberry plants in previous inoculation experiments (Stevens, 1996). For inoculation, 10 agar discs were cut using a 4-mm corkborer from the leading edge of the 20-day-old $O$. maius culture growing in MR agar medium (Mitchell and Read, 1981), placed in 400-mL MR liquid medium, and allowed to grow statically under room temperature for $20 \mathrm{~d}$. The liquid culture was then filtered through Whatman No. 1 filter paper and washed five times with distilled water. The fungal slurry and agar discs were then macerated in $100 \mathrm{~mL}$ of distilled water at $2000 \mathrm{rpm}$ in a blender for $50 \mathrm{~s}$. The 3-month-old plants were inoculated with $6 \mathrm{~mL}$ of macerated fungal mycelium (1mg dry weight of mycelinm/mL) by pouring the slurry over the plant roots. Plants were grown in triple-washed sand. Nonmycorrhizal control plants received $6 \mathrm{~mL}$ of sterile water.

Plants were then grown in a growth room at $25^{\circ} \mathrm{C}$ under $550 \mu \mathrm{mol} \cdot \mathrm{m}^{-2} \cdot \mathrm{s}^{-1}$ photosynthetically active radiation $(P A R)$ for $16 \mathrm{~h}$ daily. After 6 weeks, $24 \mathrm{M}$ and $24 \mathrm{NM}$ plants were transferred into 2-L solution culture jars, which were arranged in the growth room in a completely randomized design with four singleplant replications. The nutrient solution contained the following nutrients (in $\mathrm{mm}$ ): $2.5 \mathrm{~N}$ (as $\mathrm{NH}_{4}$ ), $0.3 \mathrm{P}, 1 \mathrm{~K}, 1 \mathrm{Mg}, 0.5 \mathrm{Ca}$, and (in $\mu \mathrm{M}$ ) 89.5 Fe (as FeEDTA), 34.2 B, 10.0 Mn, 0.99 $\mathrm{Zn}, 0.01 \mathrm{Cu}$, and $0.02 \mathrm{Mo}$. Aluminum was added $\left[\right.$ as $\left.\mathrm{Al}_{2}\left(\mathrm{SO}_{4}\right)_{3}\right]$ in the nutrient solution to give a final concentration of $200 \mu \mathrm{M} \mathrm{Al}$. This concentration was chosen based on a 2 mo. preliminary solution culture experiment, which determined that, under these conditions, 200 $\mu \mathrm{M} \mathrm{Al}$ was the minimum concentration that would adversely affect highbush blueberry plant growth. In addition, we calculated from the data of Magistad (1925) that agricultural soil solutions of $\mathrm{pH} 4.5$ can contain Al concentrations of $\approx 150 \mu \mathrm{M}$. The $\mathrm{pH}$ of the nutrient solution was adjusted to 4.5 using $0.1 \mathrm{NNaOH}$. One styrofoam cup, with a $1-\mathrm{cm}$ hole made in the bottom, was placed in the mouth of each 2L jar. The plants' stems were wrapped with a small amount of polyester fiberfill and plants were placed through the holes with their roots in the solution. The nutrient solution was aerated by aquarium-type air pumps. Immediately after the transfer, eight plants (four M and four NM) were sampled at $0 \mathrm{~h}$, and another eight plants were harvested at $1,3,5,10$, and $24 \mathrm{~h}$. A small fraction of the root sampled at 1 $\mathrm{h}$ was stained for $\mathrm{Al}$ with aurintricarboxylic acid, using the method of Maloney et al. (1982), modified by bleaching the root samples with an ammonia/peroxide solution $[10 \mathrm{~mL}$ ammonia and $100 \mathrm{~mL} \mathrm{3 \%}$ peroxide (v/v) in water] at room temperature for $30 \mathrm{~min}$, and then acidifying them in $3 \% \mathrm{HCl}$ overnight. The acidified root samples were stained at 90 ${ }^{\circ} \mathrm{C}$ for 20-30 min in a solution consisting of $0.1 \%$ aurintricarboxylic acid (w/v), 50\% glycerol, and $1 \% \mathrm{HCl}$. For all plants, dry weight was determined for leaves, stems and roots after drying at $60^{\circ} \mathrm{C}$ for $72 \mathrm{~h}$. Total $\mathrm{Al}$ 
content per plant was calculated based on leaf, stem and root $\mathrm{Al}$ concentrations determined by the aluminon method (Cabrera et al., 1981). Mycorrhizal infection level was determined by a grid-line intersect technique (Giovannetti and Mosse, 1980) modified to determine percentage of epidermal cells infected.

Root : shoot balance can affect transpiration flow (Bigot and Boucaud, 1994), thus affecting ion uptake and transport. Any differences in the percentage of root dry weight between $\mathrm{M}$ and $\mathrm{NM}$ plants could have an effect on plant root : shoot balance, which in turn might alter Al uptake. Therefore, root dry weight as a percentage of total dry weight, a statistically significant covariate, was used as a covariate for the analysis of root, leaf, and total $\mathrm{Al}$ contents, and the adjusted means are presented. Data were analyzed as a completely randomized design using the PROC MIXED procedure (SAS Institute, 1992). The significant difference between two least square means was determined by using SLICE within the LSMEANS statement and was Tukey-Kramer adjusted for mean comparisons. The test of heterogeneity of slopes (Steel and Torrie, 1980) was performed to compare the rates of $\mathrm{Al}$ uptake in $\mathrm{M}$ vs. NM plants.

Root cation exchange capacity (CEC). Freshly excised M and NM roots were washed with distilled water and transferred consecutively into five beakers containing $0.01 \mathrm{~N}$ $\mathrm{HCl}$ for $20 \mathrm{~s} \mathrm{each}$, followed by washing with distilled $\mathrm{H}_{2} \mathrm{O}$ to remove chloride. Then root CEC was determined using a titration method (Helmy and Elgabaly, 1958). The roots were placed into $15 \mathrm{~mL}$ of $1 \mathrm{~N} \mathrm{KCl}(\mathrm{pH}=8.0)$, which was stirred and titrated with $0.8 \mathrm{~mm}$ $\mathrm{KOH}$ to $\mathrm{pH} 8.0$ within 2 min, and titration volume was recorded. After titration, roots were washed with distilled $\mathrm{H}_{2} \mathrm{O}$ to remove salts and dried as before. Root CEC was expressed as meq/100 $\mathrm{g}$ of dry roots. Data were analyzed by a paired $t$ test and level of significance for the analysis of variance was $P=0.05$.

\section{Results}

Effect of $M$ infection on the plants. The inoculated plants was $11.4 \% \pm 2.3 \%$ and no infection was observed in NM plants. The percentage of infected epidermal cells in

mean dry weight of $\mathrm{M}$ plants $(0.26 \mathrm{~g})$ was not significantly different $(P=0.84)$ from that of NM plants $(0.28 \mathrm{~g})$. However, M plants had a higher percentage of root dry weight, a lower percentage of leaf dry weight (Fig. 1), and therefore a $62 \%$ higher root : shoot ratio than did NM plants.

Al uptake. Root $\mathrm{Al}$ content was higher in $\mathrm{NM}$ plants than in M plants except at $0 \mathrm{~h}$ (Fig. 2). Leaf $\mathrm{Al}$ content was higher in NM plants after 0,1 , and $5 \mathrm{~h}$, whereas stem $\mathrm{Al}$ was higher only at $5 \mathrm{~h}$. Total $\mathrm{Al}$ content of $\mathrm{M}$ plants was consistently less than that of NM plants from 0 to $10 \mathrm{~h}$; however, differences were no longer significant at $24 \mathrm{~h}$. From 0 to $24 \mathrm{~h}$, the regres-

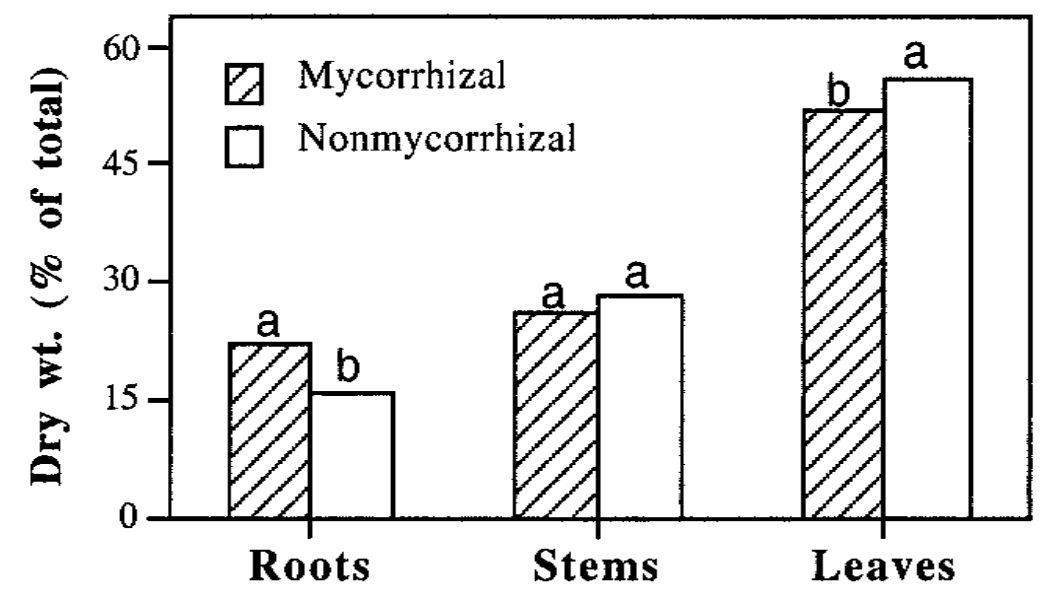

Fig. 1.Effect of mycorrhizal infection on dry weight partitioning of highbush blueberry plants. Bars labeled with the same letter are not significantly different. Mean separation between M and NM plants within organs by Fisher's LSD test, $P \leq 0.05$.
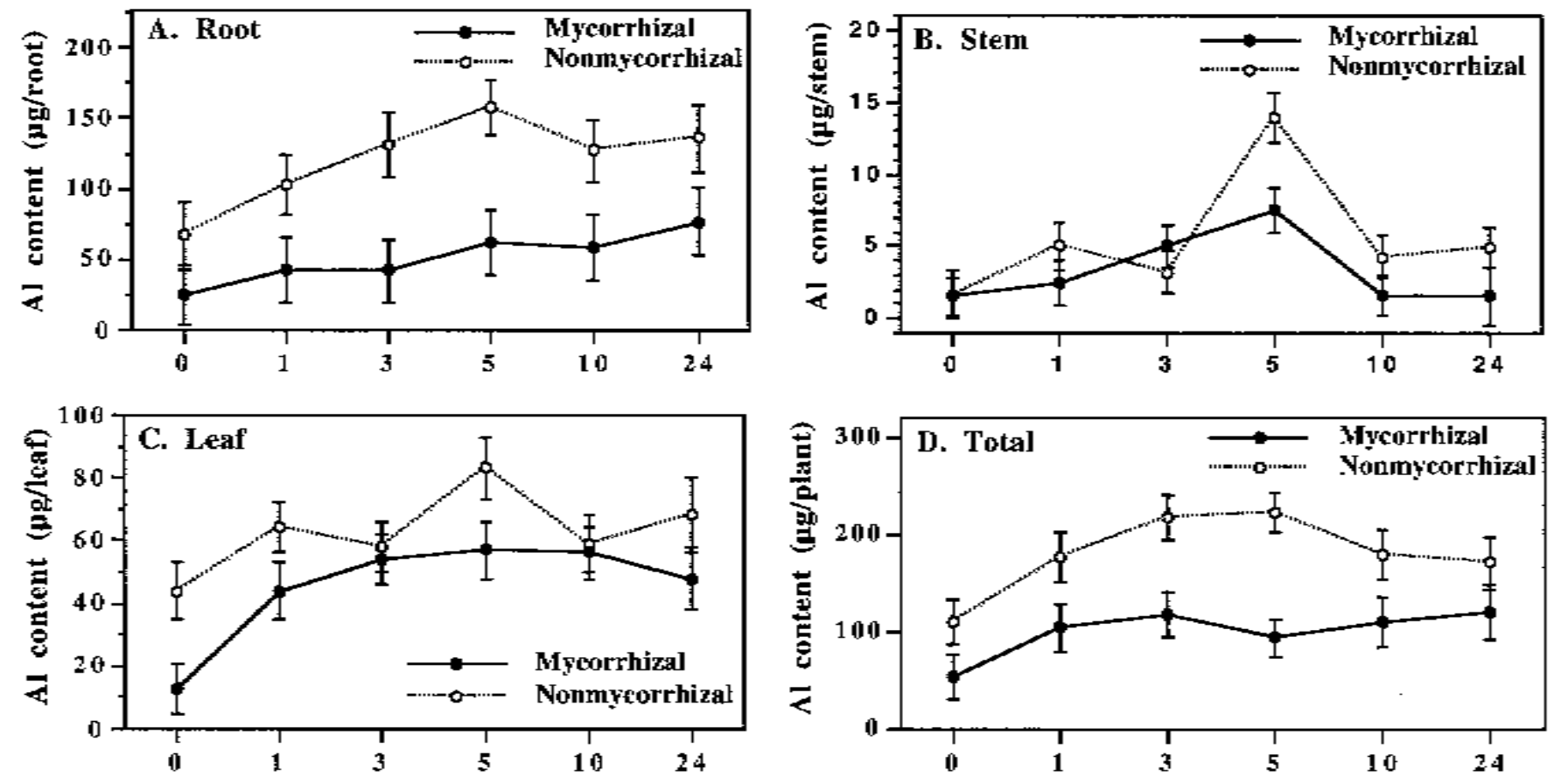

Tìme (h)

Fig. 2. Effect of mycorrhizal infection on Al content of (A) root, (B) stem, (C) leaf, (D) and entire highbush blueberry plant during 24-h exposure to Al (200 $\mu \mathrm{M})$ in nutrient solution. Each treatment mean $(n=4)$ labeled with the SE is Tukey-Kramer adjusted. 
sion coefficients (slopes) of the regression lines for root, stem, leaf, and total $\mathrm{Al}$ contents did not differ significantly for $\mathrm{M}$ and $\mathrm{NM}$ plants; however, from 0 to $5 \mathrm{~h}$, the regression coefficients for root and total $\mathrm{Al}$ content of $\mathrm{M}$ vs. NM plants were significantly different (Table 1). Specifically, NM plants took up Al at a much higher rate than did $\mathrm{M}$ plants during these first $5 \mathrm{~h}$ of exposure. The aurintricarboxylic acid stain indicated the presence of $\mathrm{Al}$ in cell walls and internal hyphal coils of the fungal symbiont in $\mathrm{M}$ roots, while in $\mathrm{NM}$ roots, $\mathrm{Al}$ appeared primarily in the cell walls and vascular tissue (Fig. 3).

Root CEC study. The CEC was signifi-

Table 1 . Heterogeneity of slopes for rate of aluminum uptake by mycorrhizal vs. nonmycorrhizal plants.

\begin{tabular}{lllll}
\hline \hline & \multicolumn{4}{c}{ Significance level $\mathrm{p}(\mathrm{F})$ for heterogeneity of slopes test } \\
\cline { 2 - 5 } Time periods $(\mathrm{h})$ & Leaf & Stem & Root & Total \\
\hline $0-24$ & $0.827^{\mathrm{z}}$ & 0.891 & 0.789 & 0.929 \\
$0-5$ & 0.841 & 0.686 & 0.002 & 0.025 \\
$5-24$ & 0.282 & 0.547 & 0.899 & 0.099
\end{tabular}

${ }^{2}$ Indicates the significance level of the regression coefficients (slopes) between the two regression lines (M and NM plants) in each graph in Fig. 2. cantly $(P \leq 0.05)$ higher in $\mathrm{M}$ than in NM roots (38.9 vs. $29.1 \mathrm{meq} / 100 \mathrm{~g} \mathrm{CEC}$, respectively).

\section{Discussion}

Higher leaf $\mathrm{Al}$ content in NM plants at $0 \mathrm{~h}$ indicated that more $\mathrm{Al}$ had been taken up by $\mathrm{NM}$ as compared to $\mathrm{M}$ plants during inoculation in the sand medium. Because $\mathrm{Al}$ was present in the medium during inoculation, the lower $\mathrm{Al}$ content in $\mathrm{M}$ plants at $\mathrm{O} \mathrm{h}$ indicates that Al uptake during infection was lower in $\mathrm{M}$ than in NM plants. As a result, prior to $\mathrm{Al}$ exposure (at $0 \mathrm{~h}$ ), NM plants had higher leaf and total Al content than M plants. Such initial differences in $\mathrm{Al}$ content therefore must be considered when analyzing short-term Al uptake. Since Al uptake over time was determined by using different plants, analysis by subtracting the initial $\mathrm{Al}$ amounts from subsequent values is not statistically feasible. Therefore the test of heterogeneity of slopes was used. The analysis showed that the reduction in Al uptake by mycorrhizal infection lasted only a short time $(5 \mathrm{~h})$ in our experimental system. Our work suggests that the pattern of Al uptake soon after exposure is highly influenced by mycorrhizal infection.

Similar studies with ericoid mycorrhizae have shown less uptake of radiocesium (Cs) and lower Cs content in M than in NM heather [Calluna vulgaris (L.) Hull] plants (Clint and Dighton, 1992). Ericoid mycorrhizae also can ameliorate the toxic effects of excessive zinc and copper and have the capacity to sequester metals in fungal tissue (Bradley et al., 1982). Eeckhaoudt et al. (1992) suggested that Al was sequestered in the ecto-mycorrhizal fungal symbiont. In our study, staining with aurintricarboxylic acid clearly showed the presence

\section{A}

Fig. 3. Location of Al in: (A) mycorrhizal root (Al present in mycorrhizal symbiont); (B) nonmycorrhizal root (Al was found on cell walls). Al was stained red using aurintricarboxylic acid (aluminon). 
of $\mathrm{Al}$ on internal hyphal coils of the infected cell, thus suggesting that Al might be sequestered there. In NM plants, Al could be taken up directly by epidermal cells and loaded into and accumulated within the negatively charged vascular tissues.

Many studies have indicated a negative correlation between root CEC and Al sensitivity (Blamey et al., 1990; Foy et al., 1967; Vose and Randall, 1962); however, root CEC in these studies was determined by using mycorrhizae-free roots. In our study, the increase in root CEC following mycorrhizal infection did not result in increased $\mathrm{Al}$ sensitivity. Because root CEC is associated with cell wall material (Burstrom, 1951), and mycorrhizal infection alters root cell structure, particularly at the fungus-cell interface (Bonfante-Fasolo and Gianinazzi-Pearson, 1979), the fungal symbiont may have been responsible for the increased CEC in M roots. The cytoplasm of the host cell is separated from the hyphae by an interfacial pectic matrix, altering cell wall structure, and therefore the CEC of $\mathrm{M}$ roots. Thus, the alteration of root CEC by $\mathrm{M}$ infection may be responsible for the reduced rate of $\mathrm{Al}$ uptake in $\mathrm{M}$ blueberry plants from 0 to $5 \mathrm{~h}$.

M plants with a larger root system (Fig. 1) and higher root CEC would be expected to accumulate more Al than NM plants. Nevertheless, M plants took up less $\mathrm{Al}$ in the first $5 \mathrm{~h}$, even prior to exposure to $\mathrm{Al}(0 \mathrm{~h})$. As demonstrated by the aurintricarboxylic acid stain for $\mathrm{Al}$ in M roots, reduced Al uptake may have been responsible for the lower total $\mathrm{Al}$ accumulation in $\mathrm{M}$ plants during the first $5 \mathrm{~h}$ because the $\mathrm{Al}$ was bound to those cation exchange (CE) sites of the mycorrhizal symbiont. Once all these CE sites were occupied by $\mathrm{Al}$ ions, Al uptake would proceed as in NM plants. Therefore, total Al content in M plants after exposure to Al did not differ from that in NM plants. The lower total Al uptake in M plants during the first $5 \mathrm{~h}$ probably reflected a lag period, during which Al was sequestered in the $\mathrm{M}$ symbiont. In an early study, mycorrhizal infection in highbush blueberry plants did not reduce Al uptake when roots were exposed to Al over a long period of time (Yang and Goulart, 1997). Note that an artificial system was used in this experiment, in which Al was constantly available at relatively high concentrations; this put more $\mathrm{Al}$ stress on plants than one would expect in most field situations. In the field, Al probably becomes available suddenly during periods of rainfall, but is re-adsorbed onto soil or organic matter as the soil dries. In normal agricultural soils at $\mathrm{pH} 4.5$, the $\mathrm{Al}$ concentration in the soil solution is usually less than $150 \mu \mathrm{M}$ (calculated after Magistad, 1925). In cases where Al concentration surges in the rhizosphere and/or soil microsite, mycorrhizal infection may reduce Al uptake in plants.

\section{Literature Cited}

Bigot, J. and J. Boucaud. 1994. Low-temperature pretreatment of the root system of Brassica rapa L. plants: Effects on the xylem sap exudation and on the nitrate absorption rate. Plant Cell Environ. 17:721-729.

Blamey, F.P.C, D.C. Edmeades, and D.M. Wheeler. 1990. Role of root cation exchange capacity in different aluminum tolerance of Lotus species. J. Plant Nutr. 13:729-744.

Bonfante-Fasolo, P. and V. Gianinazzi-Pearson. 1979. Ultrastructural aspects of endomycorrhiza in the Ericaceae.I. Naturally infected hair roots of Calluna vulgaris L. Hull. New Phytol. 83:739-744.

Bradley, R., A.J. Burt, and D.J. Read. 1982. The biology of mycorrhiza in Ericaceae VIII. The role of mycorrhizal infection in heavy metal resistance. New Phytol. 91:197-209.

Burstrom, H. 1951. The mechanism of ion absorption. p. 45-65. In: E. Truog (ed.). Mineral nutrition of plants. Univ. Wisconsin Press, Madison.

Burt, A.J., A.R. Hashem, G. Shaw, and D.J. Read. 1986. Comparative analysis of metal tolerance in ericoid and ectomycorrhizal fungi. p. 683687. In: V. Gianinazzi-Pearsson and S. Gianinazzi (eds.). Physiological and genetical aspects of mycorrhizae. Inst. Nat. de la Rech. Agr. Dijon, France.

Cabrera, F., L. Madrid, and P. de Arambarri. 1981. Use of ascorbic and thioglycollic acid to eliminate interference from iron in the aluminon method for determining aluminum. The Analyst 106:1296-1301.

Clint, G.M. and J. Dighton. 1992. Uptake and accumulation of radiocaesium by mycorrhizal and nonmycorrhizal heather plants. New Phytol. 121:555-561.

Crooke, W.M. 1958. Effect of heavy metal toxicity on the cation exchange capacity of plant roots. Soil Sci. 86:231-240.

Cumming, J.R. and L.H. Weinstein. 1990. Nitrogen source effects on Al toxicity in nonmycorrhizal and mycorrhizal pitch pine (Pinus rigida) seedlings. I. Growth and nutrition. Can. J. Bot. 68:2644-2652.

Eeckhaoudt, S., D. Vandeputte, H.V. Praag, R.V. Grieken, and W. Jacob. 1992. Laser microprobe mass analysis (LAMMA) of aluminum and lead in fine roots and their ectomycorrhizal mantles of Norway spruce (Picea abies (L.) Karst). Tree Physiol. 10:209-215.

Foy, C.D., W.H. Armiger, A.L. Fleming, and C.F. Lewis. 1967. Differential tolerance of cotton varieties to an acid soil high in exchangeable aluminum. Agron. J. 29:415-418.

Foy, C.D., R.L. Chaney, and M.C. White. 1978. The physiology of metal toxicity in plants. Annu. Rev. Plant Physiol. 29:511-566.

Giovannetti, M. and B. Mosse. 1980. An evaluation of techniques for measuring vesicular arbuscular mycorrhizal infection in roots. New Phytol. 84:489-500.
Helmy, A.K. and M.M. Elgabaly. 1958. Exchange capacity of plant roots. II. Some factors affecting the cation exchange capacity. Plant and Soil. 1:93-101.

Kennedy, C.W., W.C. Smith, and M.T. Ba. 1986. Root cation exchange capacity of cotton cultivars in relation to aluminum toxicity. J. Plant Nutr. 9:1123-1133.

Korcak, R.F. 1989. Aluminum relationships of highbush blueberries (Vaccinium corymbosum L.) Acta. Hort. 241:162-166.

Koslowsky, S.D. and R.E.J. Boerner. 1989. Interactive effects of aluminum, phosphorus, and mycorrhizae on growth and nutrient uptake of Panicum virgatum L. (Poaceae). Environ. Pollut. 61:107-125.

Maddox, J.J. and J.M. Soileau. 1991. Effects of phosphate fertilization, lime amendments, and inoculation with VA-mycorrhizal fungi on soybeans in an acid soil. Dev. Plant Soil Sci. 45:215-225.

Magistad, O.C. 1925. The aluminum content of the soil solution and its relation to soil reaction and plant growth. Soil Sci. 20:181-225.

Maloney, N.A., S.M. Ott, A.C. Alfrey, N.L. Miller, J.W. Coburn, and D.J. Sherrard. 1982. Histological quantitation of aluminum in iliac bone from patients with renal failure. J. Lab. Clin. Med. 99:206-216.

Mitchell, D.T. and D.J. Read. 1981. Utilization of inorganic and organic phosphates by the mycorrhizal endophytes of Vaccinium macrocarpon and Rhododendron ponticum. Trans. Br. Mycol. Soc. 76:225-260.

Patten, K.D., V.A. Haby, A.T. Leonard, E.W. Neuendorff, and J.V. Davis. 1988. Nitrogen source effects on rabbiteye blueberry plant-soil interactions. Commun. Soil Sci. Plant Anal. 19:1065-1074.

Peterson, D.V., C.A. Mullins, D.A. Lietzke, and D.E. Deyton. 1987. Effects of soil-applied elemental sulfur, aluminum sulfate, and sawdust on growth of rabbiteye blueberries. J. Amer. Soc. Hort. Sci. 112:612-616.

SAS Institute. 1992. SAS user's guide: Statistics. SAS Institute, Cary, N.C.

Steel, R.G.D and J.H. Torrie. 1980. Principles and procedures of statistics: A biometrical approach. 2nd ed. McGraw-Hill, New York.

Stevens, C.M. 1996. The presence, isolation, and characterization of ericoid mycorrhizal symbionts in 2 native and 2 commercial Vaccinium populations in central Pennsylvania. MS Thesis, The Pennsylvania State Univ.

Stevens, C.M., B.L. Goulart, Y.Dalpe, J.F. Hancock, K. Demchak and W.Q. Yang. 1996. The presence, isolation, and characterization of ericoid mycorrhizal symbionts in 2 native and 2 commercial Vaccinium populations in central Pennsylvania. Acta Hort. 46:411-420.

Vose, P.B. and P.J. Randall. 1962. Resistance to aluminum and manganese toxicities in plants related to variety and cation exchange capacity. Nature 196:85-86.

Yang, W.Q. and B.L. Goulart. 1997. Aluminum and phosphorus interactions in mycorrhizal and nonmycorrhizal highbush blueberry plantlets. J. Amer. Soc. Hort. Sci. 122:24-30. 